\title{
Toward greener supply chains: is there a role for the new ISO 50001 approach to energy and carbon management?
}

\author{
Ana Beatriz Lopes de Sousa Jabbour • Sílvio Aparecido Verdério Júnior • \\ Charbel José Chiappetta Jabbour • Walter Leal Filho • Lucila S. Campos • Rosani De Castro
}

Received: 14 October 2014 / Accepted: 29 August 2016/Published online: 27 September 2016

(C) The Author(s) 2016. This article is published with open access at Springerlink.com

\begin{abstract}
Considering the increased interest of stakeholders in climate change and a low-carbon economy, this article has investigated and identified several contributions of the ISO 50001 in support of the adoption of green supply chain management (GSCM). In this context, energy efficiency and reduced $\mathrm{CO}_{2}$ emissions are
\end{abstract}

\footnotetext{
A. B. L. de Sousa Jabbour

Faculty of Engineering, DMEM, University of Strathclyde, Glasgow, 75 Montrose St, Glasgow G1 1XJ, UK

e-mail: ana.jabbour@strath.ac.uk
}

\section{S. A. Verdério Júnior}

UNESP - Sao Paulo State University, Av. Eng. Ed. Carrijo Coube 14-01, (DEP-FE), Bauru, Sao Paulo, Brazil 17033360

e-mail: silviover_jr@yahoo.com.br

\section{J. C. Jabbour $(\bowtie) \cdot$ R. De Castro}

Stirling Management School, Centre for Advanced Management Education (CAME), Centre for Sustainable Practice and Living (CSPL), University of Stirling, Stirling FK9 4LA Scotland, UK e-mail: c.j.chiappettajabbour@stir.ac.uk

\section{R. De Castro}

e-mail: rosani@feb.unesp.br

\section{W. Leal Filho}

School of Science and the Environment, Manchester Metropolitan University, Chester Street, Manchester M1 5GD, UK

e-mail: w.leal@mmu.ac.uk

\section{S. Campos}

UFSC - Federal University of Santa Catarina, BrazilCampus Universitário - Trindade, 88040-970 Florianópolis

e-mail: lucila.campos@ufsc.br critical. Therefore, the proposal for and the requirements of ISO 50001 can generate useful insights on how to structure green and low-carbon supply chains, hence helping to address the challenges posed by climate change.

Keywords Climate change - Green supply chain management (GSCM) - International Organization for Standardization (ISO) $50001 \cdot$ Low-carbon supply chain management $(\mathrm{LCSCM}) \cdot$ Sustainable operations

\section{Introduction}

According to Lee (2011) and Hongjuan and Jing (2011), there is a growing concern regarding the consequences of climate change and global warming, especially in the minds of consumers. As noted by Sada et al. (2014), people's concern about a changing climate is a matter to be taken seriously. Consequently, and consistent with the outcomes of the McKinsey Global Survey (2010), the most important topics on the business agenda of more than 1500 surveyed executives in the field of environment, sustainability and biodiversity are climate change and energy efficiency.

Energy management is considered to be a combination of energy-efficient activities, techniques and process management that results in the reduction of energy costs and, inter alia, of $\mathrm{CO}_{2}$ emissions (Kannan and Boie 2003). In 2011, the International Organization for Standardization (ISO) produce the publication ISO 
50001:2011 "Energy management systems: Requirements with guidance for use" (Fiedler and Mircea 2012). Generally, standards for energy management can potentially support energy management in production processes and the creation of mechanisms to measure, control and continuously improve energy efficiency (Bruton et al. 2014; Bunse et al. 2011). Böttcher and Müller (2014) stated that ISO 50001 has a narrow focus on energy and carbon efficiency. The challenge is how to fully realise this potential.

Supply chains of all sorts are highly dependent on energy that typically originates in fossil fuels as a result of global sourcing activities and transportation modes (Halldórsson and Kovács 2010; Michelsen 2007). Therefore, $\mathrm{CO}_{2}$ emissions are generated (Oshita 2012).

In response to the challenges of climate change, managers should consider the impact of their decisions on the environment based on green supply chain management (GSCM) (Lee 2011). In order to highlight the conceptual difference between GSCM and low-carbon supply chain management (LCSCM), we can argue that LCSCM can be considered as a type of GSCM. Nishitani et al. (2016) suggested that the objective of LCSCM is to reduce greenhouse gas (GHG) emissions across entire supply chains, and therefore, the relationship between LCSCM and GHG emissions reduction in a perspective of the entire supply chains is an important issue that needs clarification.

Given that energy efficiency is important in the context of the United Nations Framework on Climate Change (COP 21) (UNFCCC 2016), that supply chains are energy intensive and generate $\mathrm{CO}_{2}$ emissions, that GSCM can be viewed as a response to the impacts of climate change, and that ISO 50001's implementation can be considered a smart and sustainable solution (Ates and Durakbasa 2012), this article aims to identify the contributions of ISO 50001 that support the adoption of GSCM practices. This work contributes with a proposal for GSCM-ISO 50001 integration, and according to Oikonomou and Jepma (2008), new proposals for discussing the interaction between environmental, energy and climate change issues are necessary in the search for climate change mitigation and adaptation.

This study is additionally justified insofar as ISO 14001, which establishes standards for an environmental management system, and is already being discussed in the GSCM context (e.g., Arimura et al. 2011; Nawrocka et al. 2009; Darnall et al. 2008; Nawrocka 2008a, b). Similarly, ISO 50001, which sets standards for an energy management system with the aim of reducing greenhouse gas emissions (Ahsen 2014), also deserves further study, including theoretical research, once this standard is new and, in particular, its importance to GSCM. At present, according to searches conducted in the ISI Web of Science and Scopus databases (until August 2016), the relationship between GSCM and ISO 50001 has not been investigated.

The proposal for GSCM-ISO 50001 integration was built on following procedures: (a) understanding the requirements from ISO 50001, (b) identifying the typical energy consumption of supply chains and making relationship between GSCM practices and (c) making assumptions about how ISO 50001 requirements can contribute for achieving GSCM practices.

This article is structured in five sections. Section 1 introduces the article's topic. Section 2 presents a brief literature review about GSCM and ISO 50001. Following, the Section 3 presents the research framework of how ISO 50001 can support and otherwise contribute to the adoption of GSCM practices. The Section 4 discusses implications of the proposal, and finally the Section 5 presents conclusion and limitation and suggests future research.

\section{Brief literature review}

Green supply chain management

Supply chain management refers to the integration of materials and information flows inbound to and outbound from a company and involves the management of the company's relationships with suppliers, supplier's suppliers, customers, customer's customers and so on. A chain includes various production and transportation steps required to supply customers with the final product (Harland 1996). The scope of a supply chain initially ranges from extraction of raw materials, their processing, transformation into components, manufacture and assembly of components into a final product. Also included are shipping and packaging involved in the previous steps until the product arrive at end customer, which requires the inclusion of distribution (storage) and retail points (Lummus and Vokurka 1999).

Environmentally, conscious business practices have received increasing attention. When environmental 
decisions are made at organisational level, they must necessarily be strategic, with internal and external implications, for managing an organisation. Accordingly, as a result of environmental impacts generated at each stage of a supply chain, green supply chain management (GSCM) decisions should start being considered (Sarkis 2003). According to Faruk et al. (2001), environmental impacts in different stages of a supply chain generally appear as follows:

(a) Purchase of raw material - consumption of materials, energy use, solid waste generation and atmospheric emissions.

(b) Pre-production - consumption of materials, energy use, solid waste and wastewater generation and atmospheric emissions.

(c) Production - consumption of energy, atmospheric emissions and solid waste and wastewater generation.

(d) Distribution - packaging (solid waste) and transportation (consumption of energy and atmospheric emissions). These elements can also be considered in the previous stages.

According to Srivastava (2007) and Min and Kim (2012), GSCM requires the integration of environmental thinking in supply chain management, including product design, selection and acquisition of materials, manufacturing processes, delivery of final products to the consumers (transportation and packaging) and the management of the end-of-life stage of the products after them useful life.

According to Golicic and Smith (2013), environmental supply chain practices are activities performed or actions taken to reduce or eliminate environmental impacts of functions or processes related to supply chain management. Zhu et al. (2008) have statistically confirmed the factors required to measure GSCM practices. These practices are internal environmental management, green purchasing, cooperation with customers, ecodesign and investment recovery. Notably, Sarkis et al. (2011) and Srivastava (2007) also consider reverse logistics to be a GSCM practice. Table 1 includes brief definitions of each GSCM practice.

There are some articles that have addressed the relationship among GSCM, energy efficiency and carbon emission topic. Rahbauer et al. (2016) identified barriers for green electricity in small and medium companies in the context of supply chain. Tognetti et al. (2015)
Table 1 Short definitions of GSCM practices

\begin{tabular}{|c|c|}
\hline GSCM practice & Definition \\
\hline $\begin{array}{l}\text { Internal environmental } \\
\text { management }\end{array}$ & $\begin{array}{l}\text { Actions of an environmental } \\
\text { management system and internal } \\
\text { environmental audit with senior and } \\
\text { middle management support in } \\
\text { addition to inter-functional integration } \\
\text { toward environmental improvements } \\
\text { in the production processes. }\end{array}$ \\
\hline Green purchasing & $\begin{array}{l}\text { Environmental concerns in selection } \\
\text { process, evaluation and auditing of } \\
\text { suppliers in addition to involvement of } \\
\text { suppliers in meeting the environmental } \\
\text { goals of organisations. }\end{array}$ \\
\hline $\begin{array}{l}\text { Cooperation with } \\
\text { customers }\end{array}$ & $\begin{array}{l}\text { Customer collaboration with cleaner } \\
\text { production, eco-design and use of } \\
\text { returnable packaging. }\end{array}$ \\
\hline Eco-design & $\begin{array}{l}\text { Design of products in consideration of } \\
\text { aspects such as ease disassembly, ease } \\
\text { of recycling, reduction of resource } \\
\text { consumption and reduction or } \\
\text { elimination of use of hazardous or } \\
\text { polluting substances. }\end{array}$ \\
\hline Investment recovery & Sale of used equipment and scrap items. \\
\hline Reverse logistics & $\begin{array}{l}\text { Reusing, recycling, remanufacturing and } \\
\text { proper disposing of products and } \\
\text { components as well as after-sales and } \\
\text { post-consumption waste. }\end{array}$ \\
\hline
\end{tabular}

Based on Zhu et al. (2005), Zhu et al. (2008), Sarkis et al. (2011).

proposed a mathematical model for reducing carbon emission in supply chain by optimisation of mix energy. Ahi and Searcy (2014) analysed metrics for energy consumption in green supply chain theme. Lee and Cheong (2011) investigated carbon emission management in an automotive supply chain. And the most of cited articles regarding supply chain and carbon emission have focused on using mathematical modelling for planning operational aspects in supply chains (e.g. Sundarakani et al. 2010). Therefore, it is possible to conclude that using a managerial perspective through ISO 50001 would be interesting in proposing integration between GSCM and energy efficiency management for reducing low carbon emission.

Given the importance of environmental issues in business practices, the extrapolation of this concern to the supply chain, primarily by recognising the potential environmental impacts at each stage of a supply chain and the of GSCM (i.e. determining the potential contributions of ISO 50001, which addresses energy efficiency and the control of greenhouse gas emissions), may be a valid 
means to guide the decision making of companies and supply chain managers. In the following section, the general guidelines of ISO 50001:2011 are presented.

\section{ISO 50001}

The purpose of ISO 50001:2011 is to enable organisations to establish the systems and processes necessary to improve energy performance, including energy efficiency, use and consumption. The implementation of this standard is expected to result in reductions in greenhouse gas emissions, energy costs and other associated environmental impacts through systematic energy management (ISO 2011).

The ISO 50001 energy management system model assists companies to develop energy-efficient targets and intervention plans, to prioritise investments in energy efficiency measures, to monitor and report the energy management performance and to ensure continuity and the constant improvement of energy efficiency (Ngai et al. 2013).

Similar to other ISO standards, ISO 50001 is based on the plan-do-check-act (PDCA) approach, which seeks continuous improvement of management systems and has been designed to be highly compatible with the leading management systems, particularly ISO 9001:2008 (quality management), ISO 14001:2004 (environmental management) and ISO 22000:2006 (food safety management). Figure 1 shows the energy management system model based on PDCA.

Based on the PDCA approach, the standard is divided into four groups of requirements, which are subdivided into other requirements. The following is a brief description of the general idea of the four groups of requirements: (a) Energy planning - based on an energy review, energy performance indicators, objectives and targets for the energy management of operations are established.

(b) Implementation and operation - consists of the requirements for operational control, design, acquisition of energy services, products, equipment and energy. Additionally, provides expertise, training and awareness building for the organisation's personnel and those working on their behalf in the pursuit of energy efficiency.

(c) Checking - consists of the monitoring, measurement, analysis and correction aspects of the procedures established to seek energy-efficient operations.

(d) Management review-assessment of internal auditing results in order to propose measures for continuous improvement in energy policy and energy performance indicators.

Based on the proposal and the general requirements of ISO 50001:2011, the following section presents a discussion on how ISO 50001 may contribute to the adoption of GSCM practices.

\section{Research framework: integration between ISO 50001 and GSCM}

ISO 14001-certified companies are more likely to consider GSCM. Thus, if companies in a supply chain cooperate, they can meet their environmental targets and reduce their environmental impacts. The continuous improvement, pollution prevention and employee training encouraged by ISO 14001 can support the structuring of GSCM actions
Fig. 1 Energy management system (EnMS) model according to ISO 50001:2011 (Source: ISO 50001 2011)

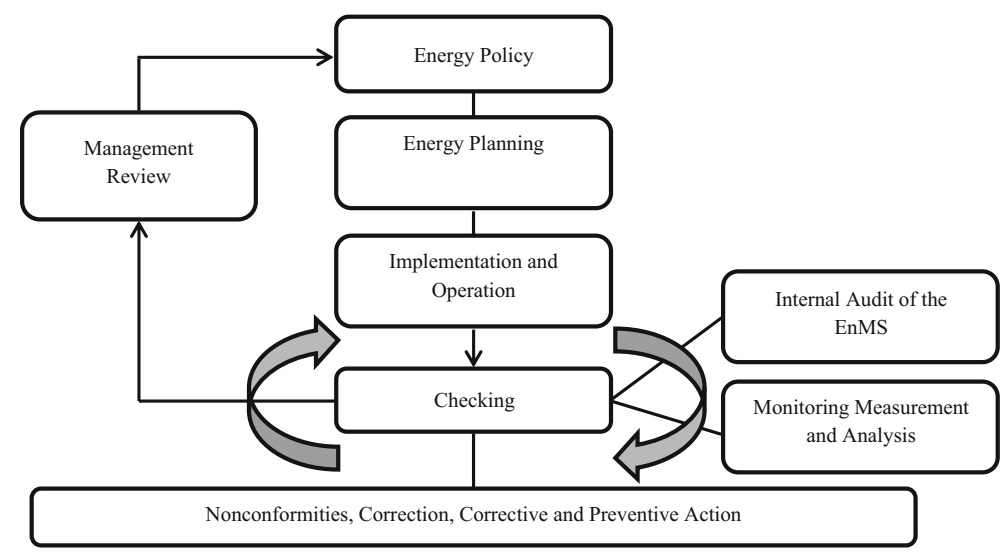


(Arimura et al. 2011). According to Darnall et al. (2008), companies that adopt an environmental management system are more likely to impose mechanisms of indirect control on suppliers, and as consequence, improving their environmental performance. Therefore, ISO 14001 can be considered as an important prerequisite to companies being ready to the adoption of GSCM (Jabbour et al. 2014), due to the fact that early adopters of environmental management system's previous developed resources and capabilities related to managing environmental impacts (Darnall et al. 2008).

Given the interrelationships between ISO 14001 and GSCM, a parallel between ISO 50001 and GSCM can also be established, primarily because according to Shen et al. (2012), ISO 50001 in particular should be promoted to ensure that energy evaluation is included in business practices.

Nishitani et al. (2016) identified that ISO 14001certified companies are able to reduce greenhouse gas, but if they adopt low-carbon supply chain principles, they will have a better performance in reducing emission. Böttcher and Müller (2014) highlighted that energy management system based on ISO 50001 can drive companies to adopt low-carbon operations. Therefore, integrating ISO 50001 to GSCM practices can pave the way to develop green and low-carbon supply chains.

According to ISO 50001, "energy" refers to the various forms of energy, including renewable ones, which can be purchased, stored, processed, used in equipment or processes or recovered, for example in the form of electricity, fuel, steam, heat and compressed. Thus, it is possible to manage the energy aspects to control and reduce the impacts of climate change at the various stages of a supply chain (Fig. 2), because according to Ürge-Vorsatz and Metz (2009), reduction of energy consumption may contribute to mitigate carbon emission.
The Fig. 2 presents each stage of a supply chain and the relationship between consumption of energy and consequent emissions. The figure aims to illustrate the importance of consider a supply chain and not only a single company because of potential amount of emissions.

ISO 50001 guidelines can support the adoption of GSCM practices to develop a green supply chain and to achieve low carbon emissions. Table 2 shows several possible contributions of ISO 50001 to GSCM.

Requirements from ISO 50001 would be integrated to green supply chains. Those may guide internal environmental management by complementing an environmental system management through proposing procedures in which aim to reduce energy consumption. It is important to highlight that employees are essential for change management towards energy efficiency (Johansson 2015), and therefore providing appropriate training should be relevant. ISO 50001 may improve green purchasing practice by including targets of saving energy and cutting emissions in monitoring and auditing of suppliers. An energy management system would be useful for raising cooperation with customers in terms of proposing energy conscious uses of products. ISO 50001 would lead eco-design practices through designing processes and products to be more energy efficient. Investment recovering practice would turn more energy efficient by replacing obsolete equipment with low energy efficiency and using highly polluting fuels with energy-efficient equipment that uses clean, renewable energy sources, for example. And, finally, requirements from ISO 50001 would advance reverse logistics practice. The perspective of recycling may be applied for energy consumption in terms of implementation of cogeneration cycles, which use by-product steam to produce electricity and use residual heat for the production of refrigeration, air conditioning and heating.
Fig. 2 Generic representation of energy consumption and environmental impacts in stages of a supply chain (Source: Based on Sarkis 2003)

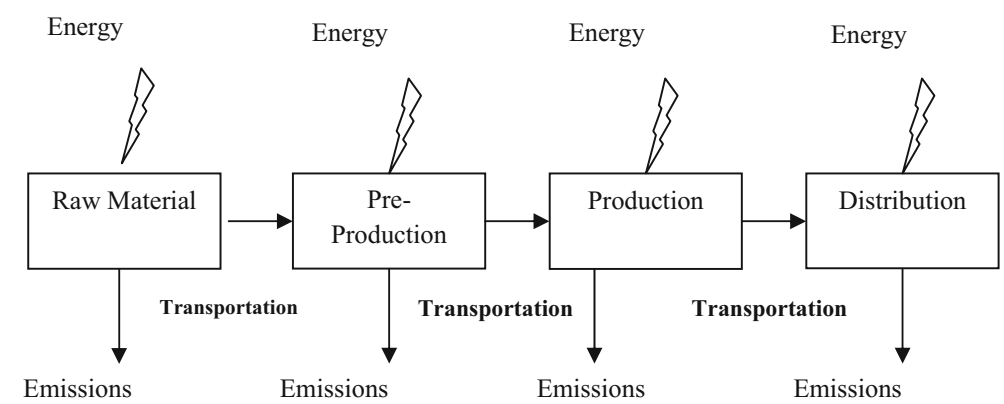


Numerous opportunities are identified for a significant increase in process efficiency and improved energy and economic performance in business organisations. These opportunities include GSCM strategies (Table 2) combined with technical solutions and alternatives for the generation, distribution and rational use of energy and (considering the principles of environmental management) techniques for cleaner production (internal recycling, for example).

To realise the potential contributions of ISO 50001, companies can use the expertise acquired with other management systems, particularly the system based on ISO 14001. The implementation of ISO 14001 creates conditions for internal staff and suppliers to become involved in the environmental improvement of the supply chain. Therefore, ISO 50001 can complement the effects of ISO 14001 to construct a supply chain that is not only greener but also low carbon, because energy efficiency results in the reduction of greenhouse gas emissions. In this sense, Table 2 can aid the decision making of managers who are considering adopting GSCM practices to mitigate the impact of their operations on global warming.

\section{Implications}

The implementation of the ISO 50001 requirements can complement the action of ISO 14001 to facilitate the construction of green and low-carbon supply chains. This outcome is possible with the adoption of GSCM practices that incorporate energy efficiency and support the control of $\mathrm{CO}_{2}$ emissions.

The institutional context tends to influence on companies to improve their environmental performance by means laws and regulation, increase of environmental awareness of customers and international market restriction, for instance (Sarkis et al. 2011). Regulatory pressures can encourage companies to adopt environmental management systems certified by ISO 14001 and, consequently, they may pursue adoption of GSCM practices (Arimura et al. 2011; Darnall et al. 2008). Zhu and Sarkis (2007) found out that pressure from government and customers affected Chinese companies in terms of adoption of eco-design and green purchasing practices. Dubey et al. (2015) also identified that institutional pressures contributed to improvement of environmental performance of Indian companies. Therefore, the external context of organisations, which has been volatile by the fact that climate change consequences, has influence on organisation decisions and organisational competitiveness.

If energy efficiency is a requirement in the context of the United Nations Framework on Climate Change (COP 21), therefore organisations will be driven by this new tendency from the institutional environment. As a consequence, organisations will seek energy and carbon efficiency, and thus integrating ISO 50001 and GSCM practices will be a key issue.

National programmes have promoted ISO 50001 and energy management system in order to rationalise use of energy in companies in Japan, the EUA and Sweden (Siciliano et al. 2015). And similar programmes have been quite often in other countries as well. The European Union (EU) has proposed energy efficiency directives in 2012 in order to control and reduce the use of energy since from producers of energy to consumers (European Commission 2016b). As a consequence, companies must audit their energy systems. Another effect of that directive is the establishment of ecodesign claims for energy-related products (European Commission 2016a). So, ISO 50001 would contribute to companies which aim to fulfil EU directives, and, especially, if companies enlarge their actions and consider the supply chain perspective.

It is possible to state that institutional theory (Zhu and Sarkis 2007) can be an organisational lens to study the transition between green supply chains to low-carbon supply chains since more and more governmental policies will require energy and low carbon efficiency from companies and supply chains. Natural resource-based view theory (Hart 1995) can complement institutional theory by highlighting unique capabilities needed to promote GSCM further.

Thus, some implications of this article are as follows. In terms of policy aspects, there will be a need for public and private investment in credit lines to assist the acquisition of cleaner technologies and software and hardware to measure, monitor and control energy equipment. In terms of businesses aspects, there will be opportunities for consulting projects to support the adoption and auditing of ISO 50001. And, in terms of organisational aspects, investments in research and development will be important to adapt or create new combustion engines for using in transportation modes that emit less $\mathrm{CO}_{2}$; in addition, investment in research and development will be relevant to improve production processes (e.g. extraction of raw material, manufacturing, assembly) to consume less energy or use renewable energy. 
Table 2 Potential contributions of ISO 50001 to green and low-carbon supply chains

\begin{tabular}{|c|c|c|}
\hline GSCM practice & ISO 50001 requirement(s) & ISO 50001 contributions to GSCM \\
\hline $\begin{array}{l}\text { Internal } \\
\text { environmental } \\
\text { management }\end{array}$ & $\begin{array}{l}\text { Energy review } \\
\text { Energy performance indicators } \\
\text { Expertise, training and awareness } \\
\text { Operational control } \\
\text { Internal auditing }\end{array}$ & $\begin{array}{l}\text { Establishing a clear energy policy, well communicated and integrated in the } \\
\text { environmental policy. Based on such policy, proposing targets for } \\
\text { reducing energy and fuel consumption as well as } \mathrm{CO}_{2} \text { emissions. } \\
\text { Identifying facilities, equipment, systems and processes that significantly } \\
\text { affect the use and consumption of energy. Creating conditions (training } \\
\text { and awareness building) and procedures to help employees perform their } \\
\text { tasks properly in consideration of environmental aspects and energy } \\
\text { efficiency. Monitoring energy related to environmental performance } \\
\text { through internal audits. } \\
\text { The experience with the environmental management system, which requires } \\
\text { the support of senior and middle management, becomes important to } \\
\text { establishing an energy management system. }\end{array}$ \\
\hline Green purchasing & $\begin{array}{l}\text { Energy review } \\
\text { Energy performance indicators } \\
\text { Design } \\
\text { Acquisition of energy services, } \\
\text { products and energy-related } \\
\text { equipment }\end{array}$ & $\begin{array}{l}\text { Identifying the members of supply chain that significantly affect the use and } \\
\text { consumption of energy. Establishing targets for the reduction of energy } \\
\text { and fuel consumption as well as of } \mathrm{CO}_{2} \text { emissions for major suppliers of } \\
\text { inputs and transportation through definitions of criteria for selection, } \\
\text { evaluation and auditing. }\end{array}$ \\
\hline $\begin{array}{l}\text { Cooperation with } \\
\text { customers }\end{array}$ & External communication design & $\begin{array}{l}\text { Collaboration with customers for better development/proper use of products } \\
\text { to avoid excessive energy consumption. Investigating if consumers are } \\
\text { willing to purchase more eco-efficient products. }\end{array}$ \\
\hline Eco-design & $\begin{array}{l}\text { Energy review } \\
\text { Energy performance indicators } \\
\text { Design } \\
\text { Acquisition of energy services, } \\
\quad \text { products and energy-related } \\
\quad \text { equipment }\end{array}$ & $\begin{array}{l}\text { Designing products and processes that aim at energy efficiency and reducing } \\
\mathrm{CO}_{2} \text { emissions. Assessing the transportation modes and the location of } \\
\text { collection points for remanufacturing and recycling to avoid excessive } \\
\text { fuel consumption and } \mathrm{CO}_{2} \text { emissions. Specifying to the suppliers of } \\
\text { materials and equipment the aspects of energy efficiency projected for the } \\
\text { end product. Establishing energy performance targets for products and } \\
\text { processes, considering more efficiency disassemble. }\end{array}$ \\
\hline $\begin{array}{l}\text { Investment } \\
\text { recovery }\end{array}$ & Energy review design & $\begin{array}{l}\text { Replacing obsolete equipment that has low energy efficiency and that uses } \\
\text { highly polluting fuels with energy-efficient equipment that uses clean, } \\
\text { renewable energy sources. } \\
\text { Investments in combined-cycle, technologies, thermal energy catchment and } \\
\text { storage systems to enable minimal use/purchase of energy during peak } \\
\text { hours. }\end{array}$ \\
\hline Reverse logistics & Energy review design & $\begin{array}{l}\text { Reuse of materials and energy. Implementation of cogeneration cycles, } \\
\text { which use the by-product steam to produce electricity. Use of residual heat } \\
\text { for production of refrigeration, air conditioning and heating. Internal and } \\
\text { external recycling of fuel waste. } \\
\text { Assessing the transportation modes and location of collection points for } \\
\text { remanufacturing and recycling to avoid excessive fuel consumption and } \\
\mathrm{CO}_{2} \text { emissions. }\end{array}$ \\
\hline
\end{tabular}

\section{Conclusion}

This article aimed to identify the contributions from ISO 50001 that would support the adoption of GSCM practices by making assumptions based on the brief literature review of the article, once this is a perspective paper type.

This article is an attempt to obtain initial insights into this current topic and requires further conceptual and empirical discussions. It has shown that there is still a critical gap between the implementation of the ISO
50001 requirements and the construction of green and low-carbon supply chains. The findings show that although the ISO 50001 was intended to harmonise and complement the effects of ISO 14001, the construction of a supply chain, which may lead to more energy efficiency results and the reduction of greenhouse gas, has its challenges.

Suggestions for future studies include the following: identifying barriers to and motivations for adopting the ISO 50001 standard in the context of supply chains to 
support the creation of public and private policy programmes to mitigate the identified barriers (cost and technical expertise tend to be critical barriers); evaluating the results and benefits of the integration of ISO 14001 and 50001 in the context of supply; verifying empirically how the Table 2 would collaborate to develop a green supply chain more efficient in terms of energy and low carbon; analysing organisational resources, which should be developed to integrate ISO 50001 and GSCM, such as green training (Jabbour and de Sousa Jabbour 2014) and teamwork based on specific technical expertise (Karcher and Jochem 2015); exploring perception of managers with regard to how the integration between ISO 50001 and GSCM contribute to a sustainable competitive advantage in a context of environmental constraints (climate change) (Hart 1995); and discussing how low-carbon supply chains enable firms to respond to the challenges and demands posed by the natural environment (Chan et al. 2015).

Some limitations of this research can be point out. The first one is that this article is exploratory. As a consequence, it presents limitations regarding the depth of the study and analysis. The fact that this study was not based on systematic literature review can also be considerate as a limitation. However, it brings insights regarding timeless subject that is aligned to international energy directives and world debate, such as the COP 21.

Acknowledgments Research reported in this work was partially supported by FAPESP - Sao Paulo State Research Foundation (Grant \# 2013/22380-8) and by CNPq-Brazilian Council for Scientific and Technological Development (Grant \#304225/ 2013-4; Grant \#303484/2013-6; Grant \# 232060/2013-4; Grant \# 303640/2013-8).

Open Access This article is distributed under the terms of the Creative Commons Attribution 4.0 International License (http:// creativecommons.org/licenses/by/4.0/), which permits unrestricted use, distribution, and reproduction in any medium, provided you give appropriate credit to the original author(s) and the source, provide a link to the Creative Commons license, and indicate if changes were made.

\section{References}

Ahi, P., \& Searcy, C. (2014). Measuring energy issues in sustainable supply chains. In Proceedings of the International Annual Conference of the American Society for Engineering Management. (p. 1).

Ahsen, A. (2014). The integration of quality, environmental and health and safety management by car manufacturers - a long- term empirical study. Business Strategy and the Environment, 23(6), 395-416.

Arimura, T. H., Darnall, N., \& Katayama, H. (2011). Is ISO 14001 a gateway to more advanced voluntary action? The case of green supply chain management. Journal of Environmental Economics and Management, 61(2), 170-182.

Ates, S. A., \& Durakbasa, N. M. (2012). Evaluation of corporate energy management practices of energy intensive industries in Turkey. Energy, 45, 81-91.

Böttcher, C., \& Müller, M. (2014). Insights on the impact of energy management systems on carbon and corporate performance. An empirical analysis with data from German automotive suppliers. Journal of Cleaner Production, in press.

Bruton, K., Raftery, P., Kennedy, B., Keane, M. M., \& O’Sullivan, D. T. J. (2014). Review of automated fault detection and diagnostic tools in air handling units. Energy Efficiency, 7(2), 335-351.

Bunse, K., Vodicka, M., Schonsleben, P., Brulhart, M., \& Ernst, F. O. (2011). Integrating energy efficiency performance in production management - gap analysis between industrial needs and scientific literature. Journal of Cleaner Production, 19, 667-679.

Chan, T. Y., Wong, C. W., Lai, K. H., Lun, V. Y., Ng, C. T., \& Ngai, E. W. (2015). Green service: construct development and measurement validation. Production and Operations Management, 25(3), 432-457.

Darnall, N., Jolley, G. J., \& Handfield, R. (2008). Environmental management systems and green supply chain management: complements for sustainability? Business Strategy and the Environment, 17(1), 30-45.

Dubey, R., Gunasekaran, A., \& Ali, S. S. (2015). Exploring the relationship between leadership, operational practices, institutional pressures and environmental performance: a framework for green supply chain. International Journal of Production Economics, 160, 120-132.

European Union. (2016a). Energy efficient products. Available on https:/ec.europa.eu/energy/en/topics/energy-efficiency/energyefficient-products. Accessed 24 Mar 2016.

European Union. (2016b). Energy efficiency directive. Available on https:/ec.europa.eu/energy/en/topics/energy-efficiency/energyefficiency-directive. Accessed 24 Mar 2016.

Faruk, A. C., Lamming, R. C., Cousins, P. D., \& Bowen, F. E. (2001). Analyzing, mapping, and managing environmental impacts along supply chains. Journal of Industrial Ecology, $5(2), 13-36$.

Fiedler, T., \& Mircea, P. M. (2012). Energy management systems according to the ISO 50001 standard - challenges and benefits. In Applied and Theoretical Electricity (ICATE), 2012 International Conference on (pp. 1-4). IEEE.

Golicic, S. L., \& Smith, C. D. (2013). A meta-analysis of environmentally sustainable supply chain management practices and firm performance. Journal of Supply Chain Management, 9(2), 7895.

Halldórsson, A., \& Kovács, G. (2010). The sustainable agenda and energy efficiency: logistics solutions and supply chains in times of climate change. International Journal of Physical Distribution \& Logistics Management, 4(1/2), 5-13.

Harland, C. M. (1996). Supply chain management: relationships, chains and networks. British Journal of Management, 7(S1), S63-S80. 
Hart, S. L. (1995). A natural-resource-based view of the firm. Academy of Management Review, 20(4), 986-1014.

Hongjuan, Y., \& Jing, Z. (2011). The strategy of advancing the cooperation satisfaction among enterprises based on low carbon supply chain management. Energy Procedia, 5, 1225-1239.

ISO (2011) ISO 50001:2011 — Energy management systems - requirements with guidance for use. International Organization for Standardization.

Jabbour, C. J. C., \& de Sousa Jabbour, A. B. L. (2014). Low-carbon operations and production: putting training in perspective. Industrial and Commercial Training, 46(6), 327-331.

Jabbour, A. B., Jabbour, C., Govindan, K., Kannan, D., \& Arantes, A. F. (2014). Mixed methodology to analyze the relationship between maturity of environmental management and the adoption of green supply chain management in Brazil. Resources, Conservation and Recycling, 92, 255-267.

Johansson, M. T. (2015). Improved energy efficiency within the Swedish steel industry - the importance of energy management and networking. Energy Efficiency, 8(4), 713-744.

Kannan, R., \& Boie, W. (2003). Energy management practices in SME--case study of a bakery in Germany. Energy Conversion and Management, 44(6), 945-959.

Karcher, P., \& Jochem, R. (2015). Success factors and organizational approaches for the implementation of energy management systems according to ISO 50001. The TQM Journal, 27(4), 361-381.

Lee, K. (2011). Integrating carbon footprint into supply chain management: the case of Hyundai motor company (HMC) in the automobile industry. Journal of Cleaner Production, $19,1216-1223$.

Lee, K. H., \& Cheong, I. M. (2011). Measuring a carbon footprint and environmental practice: the case of Hyundai Motors Co. (HMC). Industrial Management \& Data Systems, 111(6), 961-978.

Lummus, R. R., \& Vokurka, R. J. (1999). Defining supply chain management: a historical perspective and practical guidelines. Industrial Management \& Data Systems, 99(1), 11-17.

McKinsey (2010) The next environmental issue for business McKinsey Global Survey Results. https://www. mckinseyquarterly.com/The next_environmental_issue for_business_McKinsey_Global_Survey_results_2651. Cited 07 October 10.

Michelsen, O. (2007). Investigation of relationships in a supply chain in order to improve environmental performance. Clean Technologies and Environmental Policy, 9(2), 115-123.

Min, H., \& Kim, I. (2012). Green supply chain research: past, present, and future. Logistics Research, 4(1-2), 39-47.

Nawrocka, D. (2008a). Inter-organizational use of EMSs in supply chain management: some experiences from Poland and Sweden. Corporate Social Responsibility and Environmental Management, 15(5), 260-269.

Nawrocka, D. (2008b). Environmental supply chain management, ISO 14001 and RoHS. How are small companies in the electronics sector managing? Corporate Social Responsibility and Environmental Management, 15(6), 349-360.

Nawrocka, D., Brorson, T., \& Lindhqvist, T. (2009). ISO 14001 in environmental supply chain practices. Journal of Cleaner Production, 17(16), 1435-1443.

Ngai, E. W. T., Chau, D. C. K., Poon, J. K. L., \& To, C. K. M. (2013). Energy and utility management maturity model for sustainable manufacturing process. International Journal of Production Economics, 146, 453-464.
Nishitani, K., Kokubu, K., \& Kajiwara, T. (2016). Does lowcarbon supply chain management reduce greenhouse gas emissions more effectively than existing environmental initiatives? An empirical analysis of Japanese manufacturing firms. Journal of Management Control, 27(1), 33-60.

Oikonomou, V., \& Jepma, C. J. (2008). A framework on interactions of climate and energy policy instruments. Mitigation and Adaptation Strategies for Global Change, 13(2), 131-156.

Oshita, Y. (2012). Identifying critical supply chain path that drive changes in CO2 emissions. Energy Economics, 14, 1041-1050.

Rahbauer, S., Menapace, L., Menrad, K., \& Decker, T. (2016). Adoption of green electricity by small-and medium-sized enterprises in Germany. Renewable and Sustainable Energy Reviews, 59, 1185-1194.

Sada, R., Shrestha, A., Shukla, A. K., \& Melsen, L. A. (2014). People's experience and facts of changing climate: impacts and responses. International Journal of Climate Change Strategies and Management, 6(1), 47-62.

Sarkis, J. (2003). A strategic decision framework for green supply chain management. Journal of Cleaner Production, 11(4), 397-409.

Sarkis, J., Zhu, Q., \& Lai, K. (2011). An organizational theoretic review of green supply chain management literature. International Journal of Production Economics, 130(1), 1-15.

Shen, B., Price, L., \& Lu, H. (2012). Energy audit practices in China: national and local experiences and issues. Energy Policy, 46, 346-358.

Siciliano, G., de los Reyes, P., Kramer, C., Björkman, T., Dahlgren, M., Noda, F., \& Yamashita, Y. (2015). Models for driving energy efficiency nationally using energy management. Strategic Planning for Energy and the Environment, 35(2), 48-79.

Srivastava, S. K. (2007). Green supply-chain management: a stateof-the-art literature review. International Journal of Management Reviews, 9(1), 53-80.

Sundarakani, B., De Souza, R., Goh, M., Wagner, S. M., \& Manikandan, S. (2010). Modeling carbon footprints across the supply chain. International Journal of Production Economics, 128(1), 43-50.

Tognetti, A., Grosse-Ruyken, P. T., \& Wagner, S. M. (2015). Green supply chain network optimization and the trade-off between environmental and economic objectives. International Journal of Production Economics, 170, 385-392.

United Nation Framework Convention on Climate Change. (2016). COP 21 Paris. Available on http://newsroom. unfccc.int/paris/. Accessed in 24 Mar 2016.

Ürge-Vorsatz, D., \& Metz, B. (2009). Energy efficiency: how far does it get us in controlling climate change? Energy Efficiency, 2(2), 87-94.

Zhu, Q., \& Sarkis, J. (2007). The moderating effects of institutional pressures on emergent green supply chain practices and performance. International Journal of Production Research, 45(18-19), 4333-4355.

Zhu, Q., Sarkis, J., \& Geng, Y. (2005). Green supply chain management in China: pressures, practices and performance. International Journal of Operations \& Production Management, 25(5), 449-468.

Zhu, Q., Sarkis, J., \& Lai, K. (2008). Confirmation of a measurement model for green supply chain management practices implementation. International Journal of Production Economics, 111(2), 261-273. 